\title{
A CASE OF HERMAPHRODITISM IN TORTONESE'S STINGRAY, DASYATIS TORTONESEI (ELASMOBRANCHII: RAJIFORMES: DASYATIDAE) FROM THE LAGOON OF BIZERTE, TUNISIA
}

\author{
Christian CAPAPÉ ${ }^{1 *}$, Olfa EL KAMEL-MOUTALIBI ${ }^{2}$, Néjia MNASRI ${ }^{2}$, \\ Moncef BOUMAÏZA², and Christian REYNAUD ${ }^{1}$ \\ ${ }^{1}$ Laboratoire d'Ichtyologie, Université Montpellier II, Sciences et Techniques du Languedoc, Montpellier, France \\ ${ }^{2}$ Laboratoire de Bio-surveillance de l'Environnement, Unité d'Hydrobiologie Littorale et Limnique, \\ Université de Carthage, Faculté des Sciences, Zarzouna, 7021 Bizerte, Tunisia
}

Capapé C., El Kamel-Moutalibi O., Mnasri N., Boumaïza M., Reynaud C. 2012. A case of hermaphroditism in Tortonese's stingray, Dasyatis tortonesei (Elasmobranchii: Rajiformes: Dasyatidae) from the lagoon of Bizerte, Tunisia. Acta Ichthyol. Piscat. 42 (2): 141-149.

\begin{abstract}
A normal hermaphrodite Tortonese's stingray, Dasyatis tortonesei Capapé, 1975, captured in the brackish Lagoon of Bizerte (north-eastern Tunisia) is described in this note. It was a large specimen measuring $685 \mathrm{~mm}$ total length, $350 \mathrm{~mm}$ disk width, and $2190 \mathrm{~g}$ of the total body mass. The specimen externally presented medial cuspidate tooth rows on both jaws, and two claspers were present, that were rigid and calcified although shorter than those observed in normal specimens. The dissection of the abdominal cavity revealed on each side, an ovary normally developed that contained yolked oocytes, a complete genital tract and an uterus less developed than in normal adult. Conversely the testes were rudimentary, both Leydig's glands were developed and a complete, slightly convoluted, male duct existed on the left side only. In all, 13 cases of normal (4) and abnormal (9) hermaphroditism, including the Tunisian D. tortonesei, have been found in batoid species, to date, confirming that the phenomenon is very rare among these chondrichthyan fishes..
\end{abstract}

Keywords: Dasyatis tortonesei, normal hermaphrodite, Lagoon of Bizerte, Tunisia, central Mediterranean

The Tortonese's stingray, Dasyatis tortonesei Capapé, 1975, was described from specimens caught off the Tunisian coast (Capapé 1975, 1977). The species, however, was considered a junior synonym of the common stingray D. pastinaca (L.) by Séret and McEachran (1986), then re-instated as a valid species by Golani (2005) and Saad et al. (2005), based on the specimens caught in the eastern Levant Basin, and by Neifar et al. (2000) who studied the specimens caught in Tunisian waters. Kabasakal (2002) recorded $D$. tortonesei from Turkey. Outside the Mediterranean Sea, Diatta et al. (2001) recorded the species off Senegal, while Beveridge et al. (2004) considered its occurrence as possible in the Bassin of Arcachon (Atlantic coast of France).

The occurrence of $D$. tortonese $i$ was reported from the entire stretch of the Tunisian coast (Bradai et al. 2004), although it was the most common in southern areas, especially in the Gulf of Gabès, and less common in northern areas such as the Gulf of Tunis (Capapé 1989). Two specimens were first recorded on 16 January 2009 by El Kamel et al. (2009a), in the brackish Lagoon of
Bizerte, located in north-eastern Tunisia (Fig. 1). Furthermore, survey conducted in the area, between January 2007 and May 2012 yielded 25 additional specimens. In total, 27 specimens were observed including 13 males, 13 females, and an abnormal specimen, described the present note.

The abnormal specimen was captured on 14 May 2010, from the depth of approximately $9 \mathrm{~m}$, on soft bottom, off Menzel Abderrahman, close to the nautical channel $\left(37^{\circ} 13^{\prime} 03.67^{\prime \prime} \mathrm{N}\right.$ and $\left.9^{\circ} 49^{\prime} 32.28^{\prime \prime} \mathrm{E}\right)$, using commercial gill-nets of $40 \mathrm{~mm}$ stretched mesh (Fig. 2). Immediately after the capture, total length (TL) and disk width (DW) were measured to the nearest $\mathrm{mm}$, and total mass weighed to the nearest g (Fig. 3). Additionally, some organs were removed from the abdominal cavity and weighed to the nearest $\mathrm{g}$.

The abnormal D. tortonesei was $685 \mathrm{~mm}$ TL, $350 \mathrm{~mm}$ DW and weighed $2190 \mathrm{~g}$. Morphometric measurements and meristic counts, following the methodology of Golani and Capapé (2005), are given in Table 1. Two other specimens of $D$. tortonesei caught in the Lagoon of Bizerte

\footnotetext{
${ }^{*}$ Correspondence: Dr Christian Capapé, Laboratoire d'Ichtyologie, case 104, Université Montpellier II, Sciences et Techniques du Languedoc, 34095 Montpellier cedex 5 , France, phone: +33467544162, e-mail: capape@univ-montp2.fr.
} 


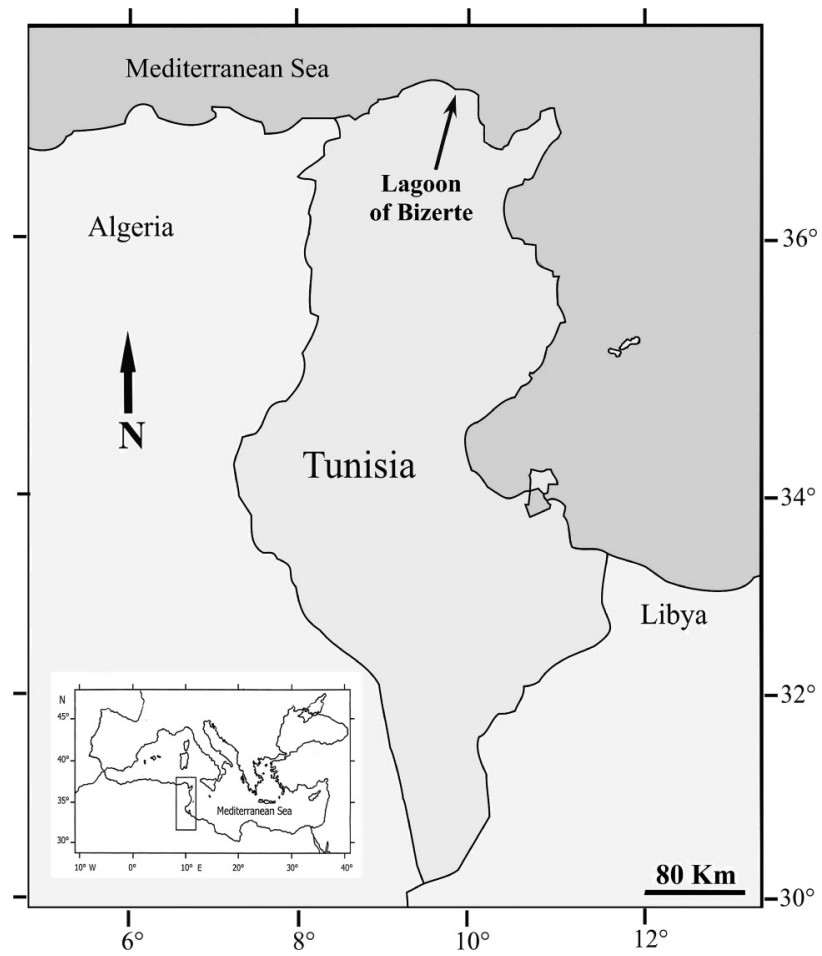

Fig. 1. Map of the Mediterranean showing Tunisia and map of the coast of Tunisia showing the collection site of hermaphrodite Tortonese's stingray, Dasyatis tortonesei (Lagoon of Bizerte)

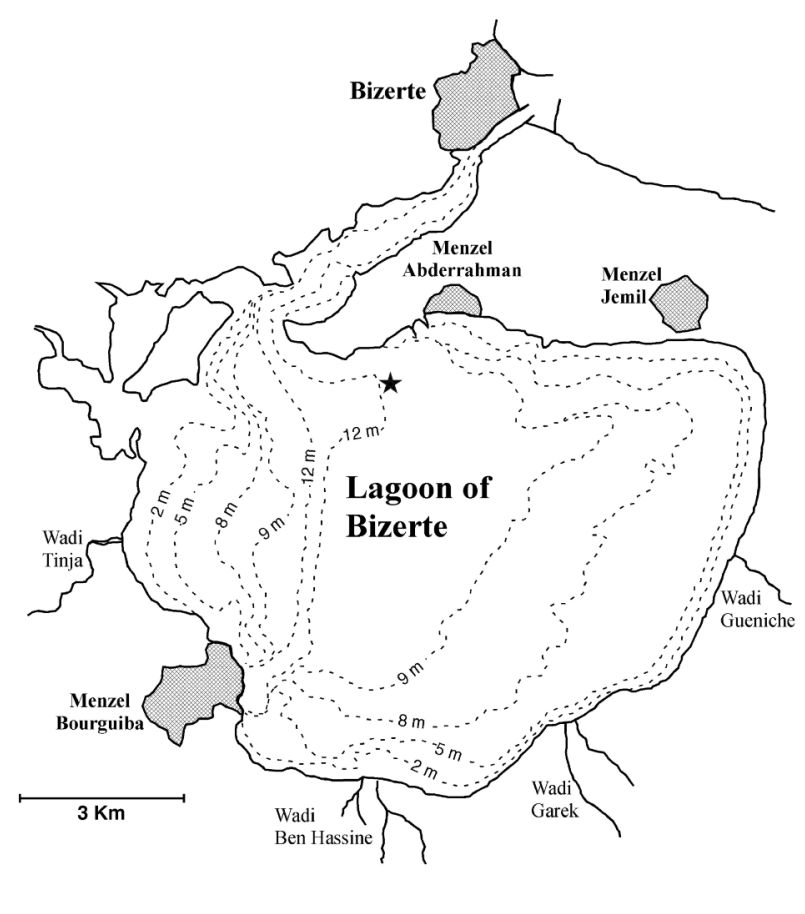

Fig. 2. Map of the Lagoon of Bizerte pointing out the capture site (black star) of the hermaphrodite specimen of Dasyatis tortonesei

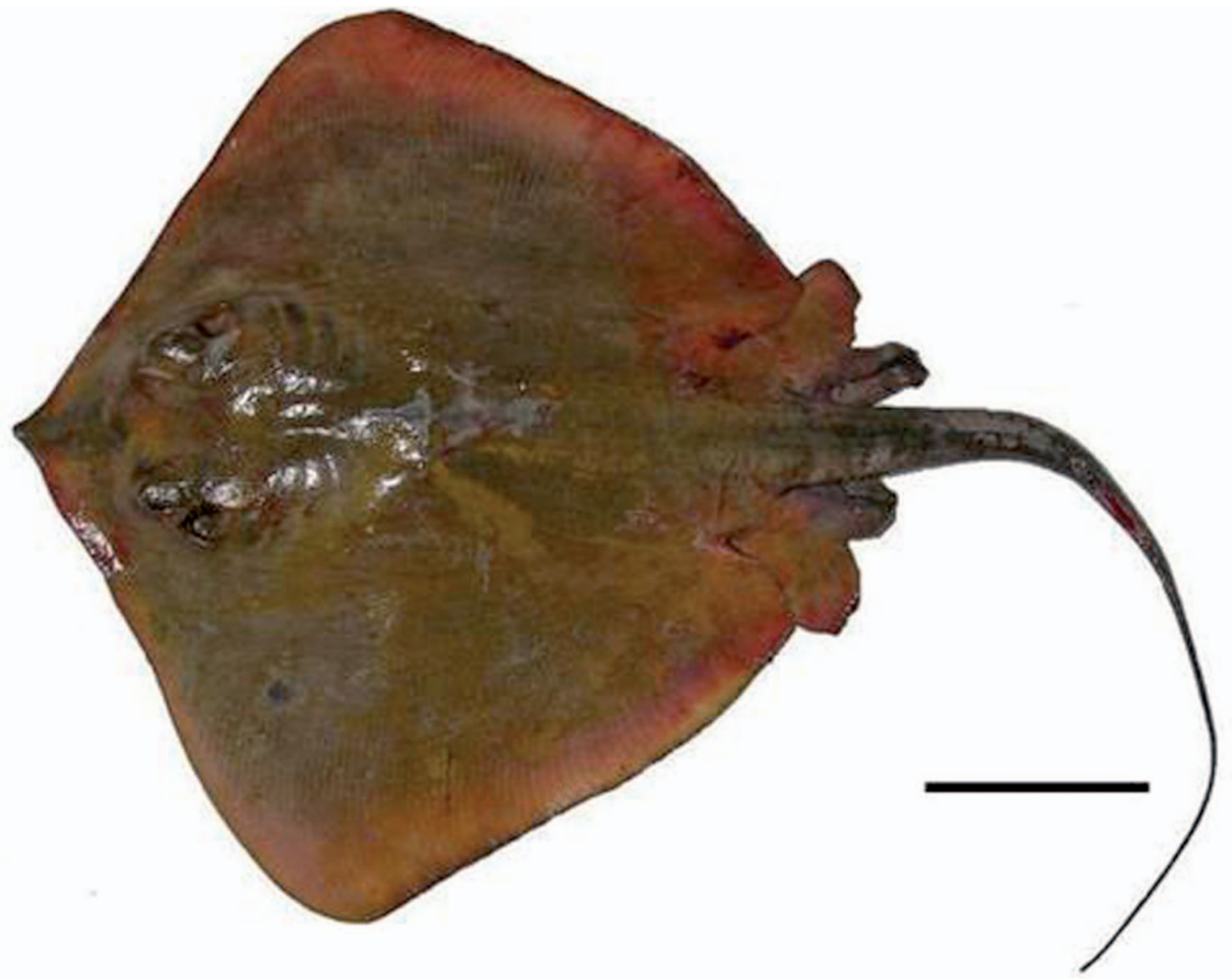

Fig. 3. Hermaphrodite specimen of Dasyatis tortonesei (FSB-D-tort 03) caught in the Lagoon of Bizerte, Tunisia; Scale bar $=100 \mathrm{~mm}$ 
Table 1

Morphometric measurements (in $\mathrm{mm}$ and as \% TL), meristic counts and masses recorded in the hermaphrodite specimen of Dasyatis tortonesei (FSB-D-tort 03) and comparison with two specimens (FSB-D-tort 04, FSB-D-tort 05)) from the Lagoon of Bizerte

\begin{tabular}{|c|c|c|c|c|c|c|}
\hline & FSB-D-tort 03 & $\% \mathrm{DW}$ & FSB-D-tort 04 & $\% \mathrm{DW}$ & FSB-D-tort 05 & $\% \mathrm{DW}$ \\
\hline Sex & Hermaphrodite & & Male & & Female & \\
\hline Total mass [g] & 2190 & & 1572 & & 1700 & \\
\hline Total lenght & 685 & 167.07 & 682 & 197.68 & 688 & 185.95 \\
\hline Disk-length & 350 & 85.37 & 308 & 89.28 & 300 & 81.08 \\
\hline Disk-width & 410 & 100.00 & 345 & 100.00 & 370 & 100.00 \\
\hline Disk depth & 70 & 17.07 & 47 & 13.71 & 64 & 17.32 \\
\hline Eyball width & 16 & 3.90 & 17 & 4.97 & 17 & 4.46 \\
\hline Cornea & 13 & 3.17 & 13 & 3.80 & 14 & 3.80 \\
\hline Pre-orbital length & 68 & 16.59 & 63 & 18.26 & 59 & 15.86 \\
\hline Inter-orbital width & 40 & 9.76 & 42 & 12.42 & 32 & 8.58 \\
\hline Spiracle length & 29 & 7.07 & 28 & 8.21 & 26 & 7.11 \\
\hline Spiracle width & 19 & 4.63 & 20 & 5.88 & 16 & 4.24 \\
\hline Inter-nasal width & 39 & 9.51 & 35 & 10.23 & 33 & 9.02 \\
\hline Nasal curtain & 44 & 10.73 & 41 & 12.02 & 39 & 10.41 \\
\hline Interspiracular width & 64 & 15.61 & 67 & 19.38 & 59 & 15.99 \\
\hline Pre-oral length & 70 & 17.07 & 65 & 18.85 & 57 & 15.31 \\
\hline Mouth width & 42 & 10.24 & 35 & 10.06 & 34 & 9.26 \\
\hline First gill slit & 11 & 2.68 & 12 & 3.53 & 12 & 3.19 \\
\hline Second gill slit & 12 & 2.93 & 12 & 3.43 & 13 & 3.41 \\
\hline Third gill slit & 13 & 3.17 & 11 & 3.29 & 13 & 3.64 \\
\hline Forth gill slit & 13 & 3.17 & 95 & 27.54 & 12 & 3.36 \\
\hline Fifth gill slit & 9 & 2.20 & 8 & 2.21 & 6 & 1.74 \\
\hline Width between first gill slit & 80 & 19.51 & 73 & 21.25 & 72 & 19.44 \\
\hline Width between fifth gill slit & 50 & 12.20 & 44 & 12.73 & 45 & 12.04 \\
\hline Snout tip to eye & 83 & 20.24 & 69 & 20.07 & 70 & 19.01 \\
\hline Snout tip to mouth & 72 & 17.56 & 69 & 20.07 & 55 & 14.95 \\
\hline Snout tip to first gill slit & 107 & 26.10 & 100 & 28.98 & 96 & 26.00 \\
\hline Snout tip to fifth gill slit & 166 & 40.49 & 148 & 42.76 & 141 & 38.14 \\
\hline Snout tip to pelvic fin & 310 & 75.61 & 265 & 76.81 & 260 & 70.27 \\
\hline Snout tip to sting & 455 & 110.98 & 418 & 121.16 & 420 & 113.51 \\
\hline Sting length & - & - & - & - & - & - \\
\hline Snout tip to vent & 293 & 71.46 & 270 & 78.26 & 275 & 74.32 \\
\hline Pectoral fin anterior margin & 240 & 58.54 & 205 & 59.42 & 220 & 59.46 \\
\hline Pectoral fin posterior margin & 227 & 55.37 & 200 & 57.97 & 220 & 59.46 \\
\hline Pectoral fin inner margin & 52 & 12.68 & 43 & 12.59 & 31 & 8.42 \\
\hline Pelvic fin anterior margin & 59 & 14.39 & 61 & 17.67 & 63 & 17.00 \\
\hline Pelvic fin posterior margin & 40 & 9.76 & 52 & 15.11 & 53 & 14.22 \\
\hline Pelvic fin inner margin & 21 & 5.12 & 16 & 4.63 & 26 & 6.91 \\
\hline Pelvic fin base & 34 & 8.29 & 30 & 8.74 & 49 & 13.21 \\
\hline Span of pelvic fin & 142 & 34.63 & 148 & 43.01 & 142 & 38.25 \\
\hline Clasper length & 90 & 21.95 & 137 & 39.71 & - & 0.00 \\
\hline Tail base width & 36 & 8.78 & 28 & 8.16 & 29 & 7.96 \\
\hline Tail base depth & 21 & 5.12 & 21 & 6.01 & 20 & 5.39 \\
\hline Tail length & 365 & 89.02 & 395 & 114.49 & 380 & 102.70 \\
\hline Ventral tail fold length & 113 & 27.56 & 102 & 29.48 & 129 & 34.86 \\
\hline Dorsal tail fold length & 42 & 10.24 & 25 & 7.25 & 18 & 4.96 \\
\hline \multicolumn{7}{|l|}{ Counts } \\
\hline Oral papillae & 29 & & 28 & & 28 & \\
\hline Bucal papillae & $1+3+1$ & & $1+3+1$ & & $1+3+1$ & \\
\hline Teeth rows upper jaw & 47 & & 45 & & 45 & \\
\hline Teeth rows lower jaw & 42 & & 39 & & 42 & \\
\hline
\end{tabular}


were added for comparison. The parameters presented in Table 1 were consistent with previous accounts of $D$. tortonesei provided by Capapé (1977) and Mc Eachran and Capapé (1984). The three specimens were preserved and deposited in the Ichthyological Collection of the Faculté des Sciences de Bizerte, with catalogue numbers, FSB-D-tort 03, 04 , and 05 respectively.

The analysis of the medial tooth rows on both jaws of the abnormal specimen showed that they were the typical cuspidate teeth of males, described in dasyatid species (Mc Eachran and Capapé 1984). Both claspers were present, rigid and calcified but shorter than those observed in normal specimens (Capapé 1983); additionally their distal end was not elongate and sharp but broadly rounded, although entirely covered by skin; no scar was visible; the teeth were probably functional (Fig. 4). Both claspers were measured following methodology of Collenot (1969), the left clasper, $90 \mathrm{~mm}$, being slightly smaller than the right one, $92 \mathrm{~mm}$. Additionally, the clasper of the hermaphrodite specimen was smaller that this of the normal specimen of similar size (Table 1). The loss of tail clasper was the consequence of an abnormal development during growth, and not the result of a predation, such pat- tern was rather reported for tail of skate species (Mnasri et al. 2009, Orlov 2011).

Dissection of the abdominal cavity allowed the primary sexual characters to be investigated (Fig. 5). Two ovaries were present and contained large yolked oocytes (Fig. 6); the left ovary weighed $35.9 \mathrm{~g}$ and contained 16 oocytes ranging in diameter from 17 to $21 \mathrm{~mm}$, the right ovary weighed $22.9 \mathrm{~g}$ and contained 16 oocytes ranging in diameter from 13 to $18 \mathrm{~mm}$. Both spermiducts were developed, the oviducal gland was more developed in the right side, while two uteri were present, the left uterus appeared to be more developed than the right one, but less than those generally observed in normal female specimens. Occurrence of two ovaries and two uteri could be considered a morphological aberration in a dasyatid species, in which only a single ovary and a single uterus are functional in large specimens (Mellinger 1989).

The specimen exhibited two Leydig's gland normally developed and two rudimentary testes, both spermiducts were present and slightly convoluted, although no sperm was found in either ducts. In adult male of $D$. tortonesei, as in other dasyatid species, the genital apparatus is typically fully developed on both sides (Capapé 1978,

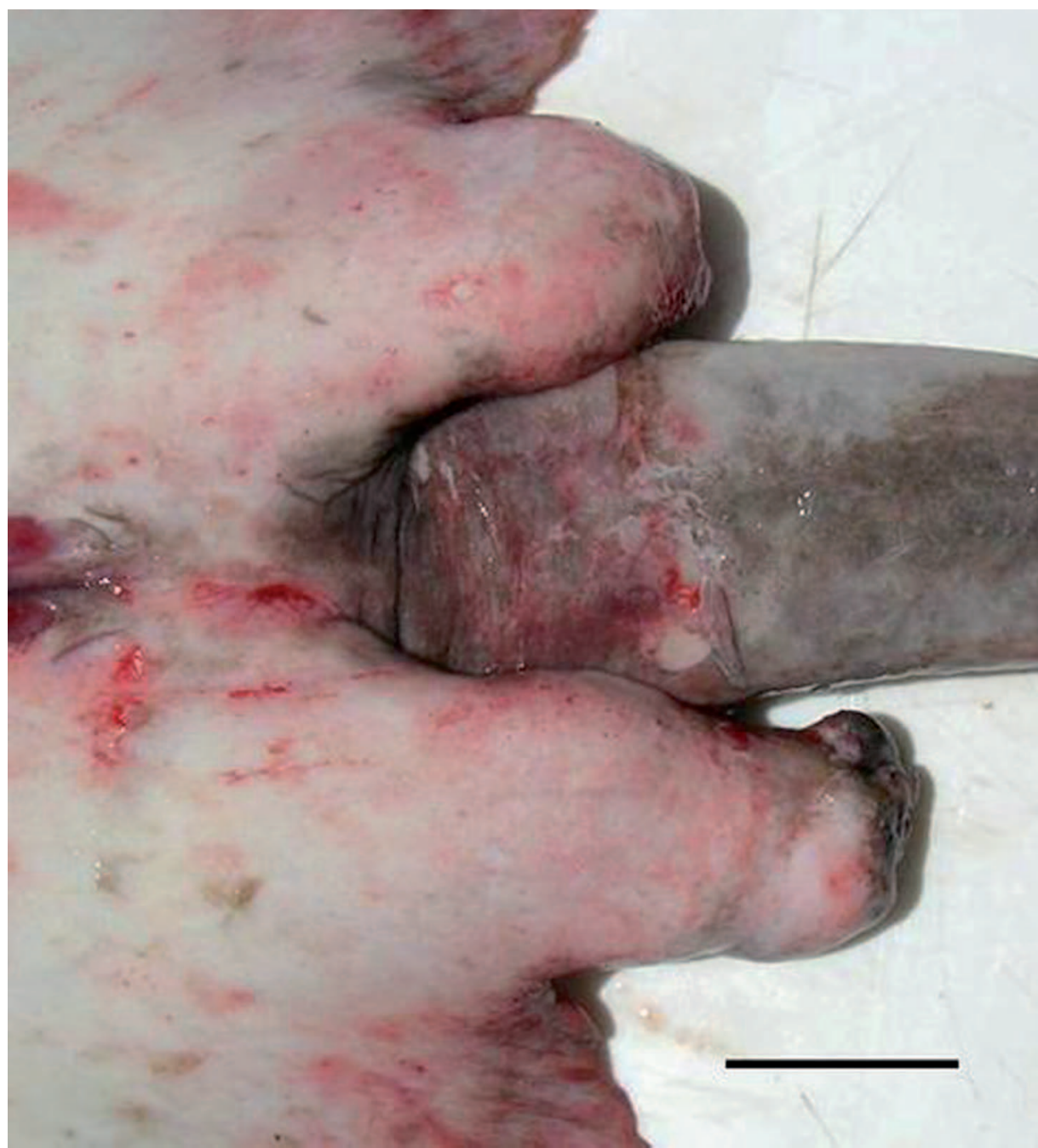

Fig. 4. Claspers of the hermaphrodite specimen of Dasyatis tortonesei caught in the Lagoon of Bizerte, Tunisia; Scale bar $=20 \mathrm{~mm}$ 
Mellinger 1989). The liver mass was $123.9 \mathrm{~g}$, the digestive tract mass was $67.7 \mathrm{~g}$. The gut contained remains of food totally digested and unidentifiable, weighing approximately $1 \mathrm{~g}$.

Of the three categories of abnormalities reported by Dawson (1964, 1966, 1971) and Dawson and Heal (1971) in chondrichthyans, hermaphroditism is probably the most interesting due to the fact that it directly concerns reproductive organs and reproduction. Atz (1964) noted that hermaphroditism was rarely recorded in chondrichthyans. Two types of hermaphroditism are generally reported in chondrichthyans such as 'abnormal hermaphrodite' and 'normal hermaphrodite' following Atz (1964) and Iglésias et al. (2005), defined also as 'pseudo-hermaphrodite' and 'true hermaphrodite' by Irvine et al. 2002. Normal hermaphrodites or true-hermaphrodites exhibit internally both sexes with claspers and when mature it could assume functions of both male and female, all other cases of hermaphroditism would be defined as abnormal or pseudohermaphroditism (Irvine et al. 2002, Iglésias et al. 2005).

Additionally, Atz (1964) and Bortone and Davis (1994) noted that intersexuality is considered when primary or secondary characters of both sexes are present in a same specimen.

Externally, the studied specimen exhibited, male secondary characters such as cuspidate teeth and claspers. Internally, it possessed developed female organs and yolked oocytes of ovulatory size; so it could be considered a functioning adult female. On the other hand, the male reproductive organs are consistent with a sub-adult male, totally developed in the left side only, even if the structure of both claspers are characteristic of an adult

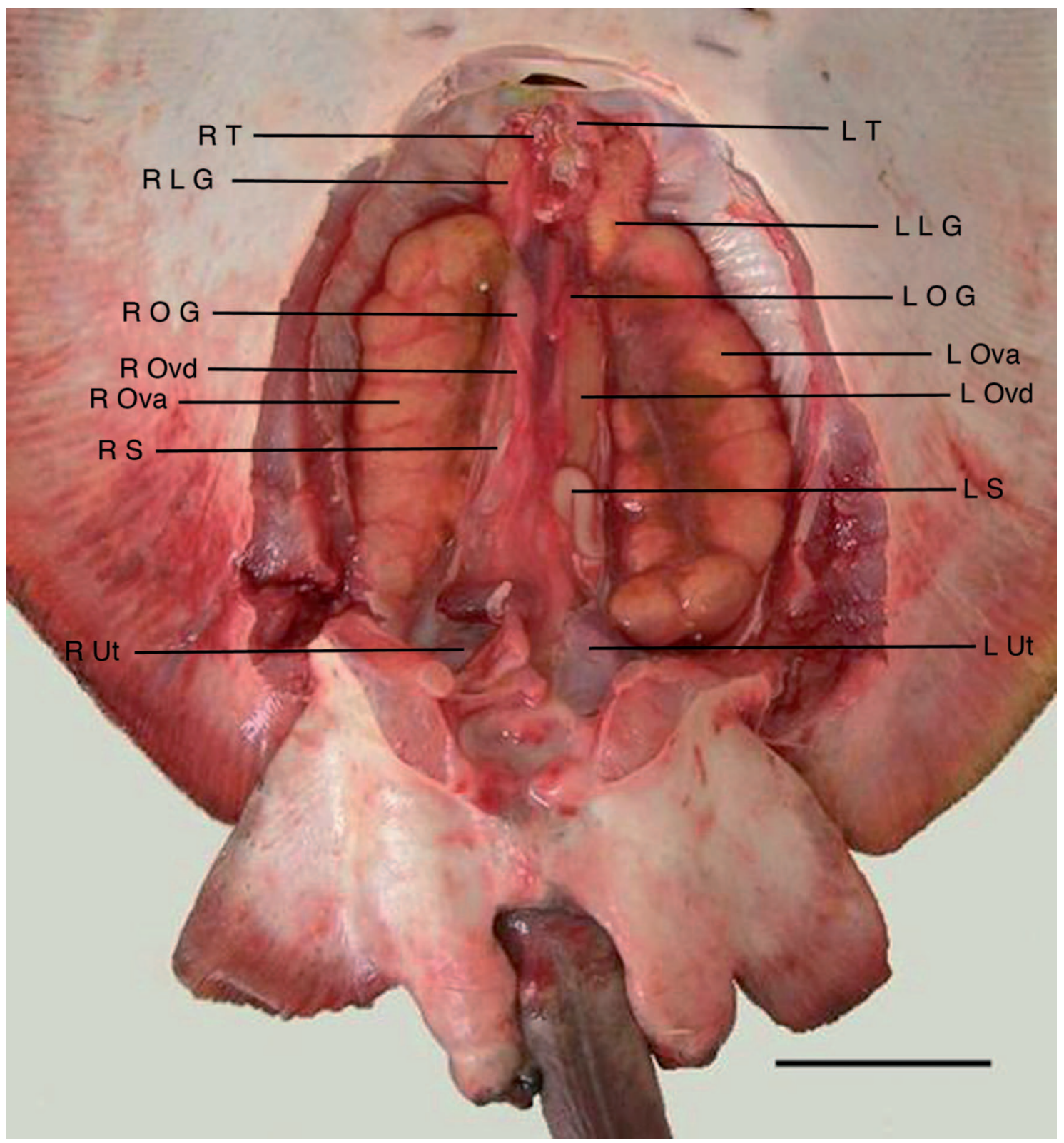

Fig. 5. Ventral view of the abdominal cavity of the hermaphrodite specimen of Dasyatis tortonesei caught in the Lagoon of Bizerte, Tunisia; showing on left side (L) and on right side (R): Leydig's gland (LG), oviducal gland $(\mathrm{OG})$, ovary (Ova), oviduct $(\mathrm{Ovd})$, spermiduct $(\mathrm{S})$, testis $(\mathrm{T})$, uterus $(\mathrm{Ut})$; Scale bar $=40 \mathrm{~mm}$ 


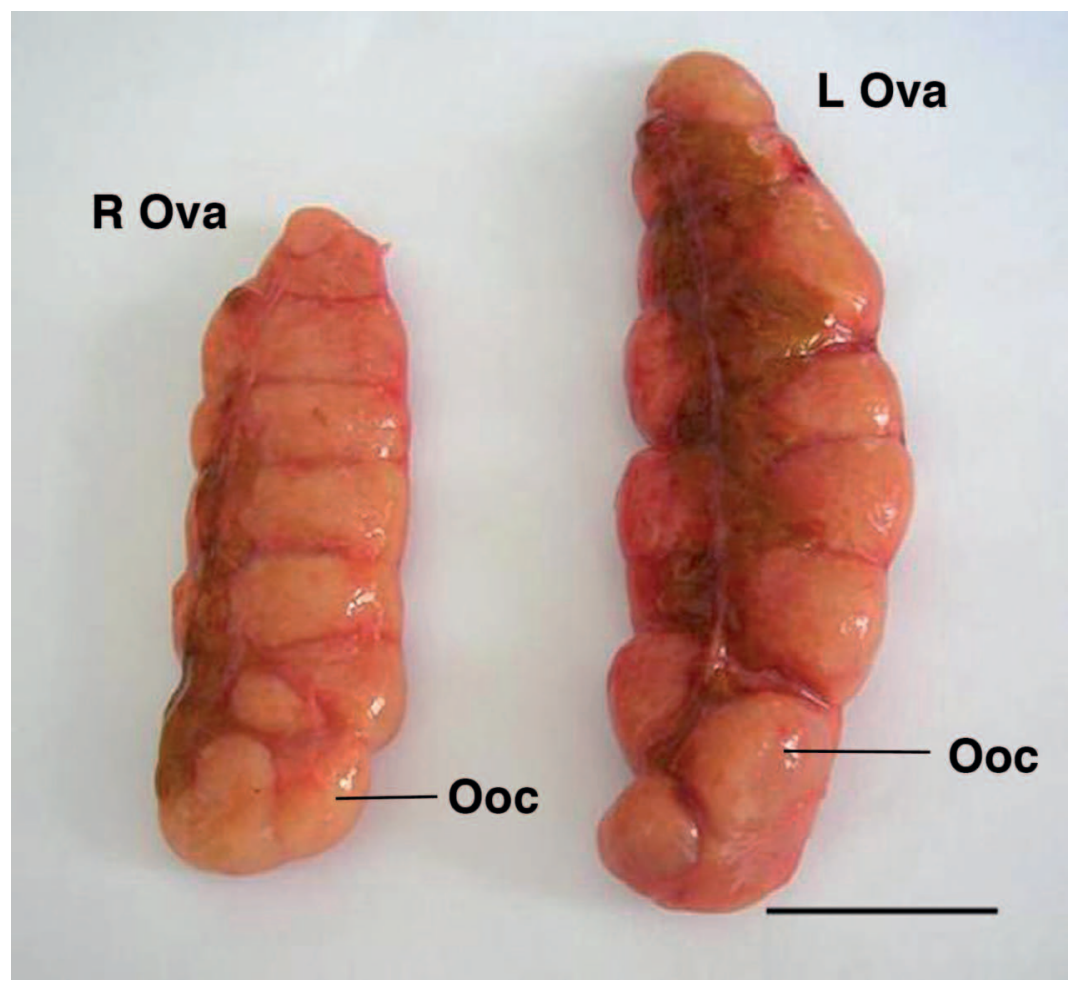

Fig. 6. Left ovary (L Ova) and right ovary (R Ova) removed from the abdominal cavity of the hermaphrodite specimen of Dasyatis tortonesei caught in the Lagoon of Bizerte, Tunisia; oocyte (Ooc); Scale bar $=25 \mathrm{~mm}$

Table 2

Normal and abnormal cases of hermaphroditism recorded in batoid species from other marine regions, including the specimen described in this note

\begin{tabular}{|c|c|c|c|c|c|}
\hline Family & Species & Hermaphroditism & $\begin{array}{l}\text { Reproductive } \\
\text { mode }\end{array}$ & Capture site & Reference \\
\hline Rhinobatidae & Rhinobatos horkelii & Normal & $\begin{array}{l}\text { Aplacental } \\
\text { viviparous }\end{array}$ & $\begin{array}{l}\text { Southern coast } \\
\text { of Brazil }\end{array}$ & Gianeti and Vooren 2007 \\
\hline Narcinidae & Narcine timlei & Normal & $\begin{array}{l}\text { Aplacental } \\
\text { viviparous }\end{array}$ & Coast of India & $\begin{array}{l}\text { Nair } \\
\text { and Soundararajan } 1973\end{array}$ \\
\hline Torpedinidae & Torpedo marmorata & Abnormal & $\begin{array}{l}\text { Aplacental } \\
\text { viviparous }\end{array}$ & Coast of Tunisia & Capapé 1974 \\
\hline Torpedinidae & Torpedo torpedo & Abnormal & $\begin{array}{l}\text { Aplacental } \\
\text { viviparous }\end{array}$ & Coast of Tunisia & $\begin{array}{l}\text { Quignard } \\
\text { and Negla } 1971\end{array}$ \\
\hline Arhynchobatidae & $\begin{array}{l}\text { Bathyraja } \\
\text { multispinis }\end{array}$ & Abnormal & Oviparous & Coast of Argentina & Scenna et al. 2007 \\
\hline Rajidae & Raja asterias & Abnormal & Oviparous & $\begin{array}{l}\text { French } \\
\text { Mediterranean coast }\end{array}$ & $\begin{array}{l}\text { Quignard } \\
\text { and Negla } 1971\end{array}$ \\
\hline Rajidae & R. clavata & Abnormal & Oviparous & British waters & $\begin{array}{l}\text { Matthews } 1895 \\
\text { (in Atz 1964) }\end{array}$ \\
\hline Rajidae & R. clavata & Abnormal & Oviparous & $?$ & $\begin{array}{l}\text { Hoek } 1894 \\
\text { (in Atz 1964) }\end{array}$ \\
\hline Rajidae & R.miraletus & Normal & Oviparous & Coast of Tunisia & $\begin{array}{l}\text { Quignard } \\
\text { and Capapé } 1972\end{array}$ \\
\hline Rajidae & R.miraletus & Abnormal & Oviparous & Coast of Tunisia & $\begin{array}{l}\text { Quignard } \\
\text { and Capapé } 1972\end{array}$ \\
\hline Dasyatidae & Dasyatis tortonesei & Normal & $\begin{array}{l}\text { Aplacental } \\
\text { oviparous }\end{array}$ & $\begin{array}{l}\text { Lagoon of Bizerte } \\
\text { (Tunisia) }\end{array}$ & This study \\
\hline Dasyatidae & $\begin{array}{l}\text { Pteroplatytrygon } \\
\text { violacea }\end{array}$ & Abnormal & $\begin{array}{l}\text { Aplacental } \\
\text { viviparous }\end{array}$ & $\begin{array}{l}\text { Southern coast } \\
\text { of Brazil }\end{array}$ & Ribeiro-Prado et al. 2009 \\
\hline Myliobatidae & $\begin{array}{l}\text { Aetomylaeus } \\
\text { nichofii }\end{array}$ & Abnormal & $\begin{array}{l}\text { Aplacental } \\
\text { viviparous }\end{array}$ & $\begin{array}{l}\text { Indian Ocean } \\
\text { (off Pakistan?) }\end{array}$ & $\begin{array}{l}\text { Capapé } \\
\text { and Desoutter } 1979\end{array}$ \\
\hline
\end{tabular}


male. It appears that the specimen could subsequently assume the function of male, but such hypothesis remains suitable. The specimen was a normal or true hermaphrodite following the definitions of Atz (1964), Irvine et al. (2002), and Iglésias et al. (2005). The presently reported observation is likely to be the first case of a true hermaphrodite in a dasyatid species. Previously, Ribeiro-Prado et al. (2009) described an abnormal hermaphrodite of the pelagic stingray, Pteroplatytrygon violacea (Bonaparte, 1832).

Although such abnormalities are considered rare in chondrichthyans, a high percentage of true hermaphrodites were observed in the brown lantern shark, Etmopterus unicolor (Engelhardt, 1912), by Yano and Tanaka (1989) and the black dogfish, Centroscyllium fabricii (Reinhardt 1825), by Yano (1995), while Iglésias et al. (2005) stated that hermaphroditism is the normal condition of reproduction in the longhead catshark, Apristurus longicephalus Nakaya, 1975. No similar patterns were reported in batoid species, from which, few instances were recorded, only 15, to date (Table 2).

The causes of hermaphroditism in chondrichthyans remain obscure. Atz (1964) noted that they may be due to endogenous-, hormonal-, or genetic factors as in other vertebrate species. Abnormalities in fish species occur during the early stages of development and could constitute an important indicator on unfavourable environmental conditions and pollutants, induced stress in the wild (Sfakianakis et al. 2004). Heavy metals such as Cd, Pb, $\mathrm{Zn}$, and $\mathrm{Cu}$ are suspected to cause reduction or absence of fins (Sloof 1982). Several cases of abnormalities were described from animal species collected in the Lagoon of Bizerte, a restricted brackish area polluted by both inorganic and organic nutriments and heavy metals (Mzoughi et al. 2002, Harzallah 2003). Louiz et al. (2007) noted that skeletal deformities observed in 3 gobiid species were significantly higher in the areas severely polluted. Such pollution could explain why abnormal specimens of Torpedo torpedo (L.) were reported from the Lagoon of Bizerte (Ben Brahim and Capapé 1997, Ben Brahim et al. 1998, El Kamel et al. 2009b, Mnasri et al. 2010, El KamelMoutalibi et al. 2011), common torpedoes such as stingrays live buried in sandy bottoms, known to accumulate pollutants. The role of pollution in hermaphroditism concerning elasmobranch species seems to be worth further investigations.

\section{ACKNOWLEDGEMENTS}

The authors wish to thank three anonymous referees for helpful and useful comments that allowed improving the manuscript.

\section{REFERENCES}

Atz J.W. 1964. Intersexuality in fishes. Pp. 145-232. In: Armstrong C.N., Marshall A.J. (eds.). Intersexuality in vertebrates including man. Academic Press, London.

Ben Brahim R., Capapé C. 1997. Nageoire dorsale supplémentaire chez une torpille ocellée, Torpedo (Torpedo) torpedo des eaux tunisiennes (Méditerranée centrale). Cybium 21 (2): 223-225.
Ben Brahim R., Seck A.A., Capapé C. 1998. Albinisme chez la torpille ocellée, Torpedo (Torpedo) torpedo (Linnaeus, 1758). Cybium 22 (1): 83-86.

Beveridge I., Neifar L., Euzet L. 2004. Review of the genus Progrillotia Dollfus, 1946 (Cestoda: Trypanorhyncha), with a redescription of Progrillotia pastinacae Dollfus, 1946 and description of Progrilliota dasyatidis sp. n. Folia Parasitologica 51 (1): 33-44.

Bortone S.A., Davis W.P. 1994. Fish intersexuality as indicator of environmental stress. Monitoring fish reproductive systems can serve to alert humans to potential harm. BioScience 44 (3): 165-172.

Bradai M.N., Quignard J.-P., Bouain A., Jarboui O., Ouannes-Ghorbel A., Ben Abdallah L., Zaouali J., Ben Salem S. 2004. Ichtyofaune autochtone et exotique des côtes tunisiennes: Recensement et biogéographie. Cybium 28 (4): 315-328.

Capapé C. 1974. Anomalie de l'appareil urogénital chez Torpedo (Torpedo) marmorata Risso, 1810. Archives de l'Institut Pasteur de Tunis 51 (4): 321-328.

Capapé C. 1975. Sélaciens nouveaux et rares le long des côtes tunisiennes. Premières observations biologiques. Archives de l'Institut Pasteur de Tunis 52 (1-2): 107-128.

Capapé C. 1977. Les espèces du genre Dasyatis Rafinesque, 1810 (Pisces, Rajiformes) des côtes tunisiennes. Cybium 3 ème série 2: 75-105.

Capapé C. 1978. Contribution à la biologie des Dasyatidæ des côtes tunisiennes. III. Dasyatis tortonesei Capapé, 1975. Répartition géographique et bathymétrique, sexualité, reproduction, fécondité. Bulletin de l'Institut national scientifique et technique d'Océanographie et de Pêche de Salammbô 5: 97-110.

Capapé C. 1983. Nouvelles données sur la morphologie des Dasyatidæ (Pisces, Rajiformes) des côtes tunisiennes. Bulletin de l'Institut national scientifique et technique d'Océanographie et de Pêche de Salammbô 10: 69-98.

Capapé C. 1989. Les Sélaciens des côtes méditerranéennes: aspects généraux de leur écologie et exemples de peuplements. Océanis 15 (3): 309-331.

Capapé C., Desoutter M. 1979. Nouvelle description de Aetomylaeus nichofii (Bloch et Schneider, 1801) (Pisces, Myliobatidæ). Premières observations biologiques. Cahiers de l'Indo-Pacifique 1 (3): 305-322.

Collenot G. 1969. Etude biométrique de la croissance relative des ptérygopodes chez la roussette Scyliorhinus canicula L. Cahiers de Biologie marine 10 (4): 309-329.

Dawson C. 1964. A bibliography of anomalies of fishes. Gulf Research Reports 1 (6): 308-399.

Dawson C. 1966. A bibliography of anomalies of fishes. Gulf Research Reports 2 (2): 169-176.

Dawson C. 1971. A bibliography of anomalies of fishes. Gulf Research Reports 3 (2): 215-239.

Dawson C., Heal E. 1971. A bibliography of anomalies of fishes. Gulf Research Reports supplement 35 (2): 35-41.

Diatta Y., Clotilde-Ba F.L., Capapé C. 2001. Rôle trophique $\mathrm{du}$ poulpe commun, Octopus vulgaris, chez les Elasmobranches de la côte du Sénégal (Atlantique oriental tropical). Comparaison avec les espèces des côtes tunisiennes (Méditerranée centrale). Acta Adriatica 42 (1): 77-88. 
El Kamel O., Mnasri N., Ben Souissi J., Boumaïza M., Ben Amor M.M., Capapé C. 2009a. Inventory of elasmobranch species caught in the Lagoon of Bizerte (north-eastern Tunisia, central Mediterranean). Pan-American Journal of Aquatic Sciences 4 (4): 383-412.

El Kamel O., Mnasri N., Boumaïza M., Capapé C. 2009b. Atypical abnormality in a common torpedo, Torpedo torpedo (Chondrichthyes: Torpedinidae) from the Lagoon of Bizerte (northern Tunisia, central Mediterranean). Cahiers de Biologie Marine 50 (1): 97-101.

El Kamel-Moutalibi O., Mnasri N., Boumaïza M., Reynaud C., Capapé C. 2011. Abnormalities in common torpedos, Torpedo torpedo (Chondrichthyes: Torpedinidae) from the Lagoon of Bizerte (Northern Tunisia, Central Mediterranean). Annales Series Historia Naturalis 20 (2): 181-190.

Gianeti M.G., Vooren C.M. 2007. A hermaphrodite guitarfish, Rhinobatos horkelii (Müller \& Henle, 1841) (Rajiformes:Rhinobatidae), from southern Brazil. Cahiers de Biologie Marine 48 (4): 407-409.

Golani D. 2005. Check-list of the Mediterranean Fishes of Israel. Zootaxa 2005 (947): 1-200.

Golani D., Capapé C. 2005. First records of the blue stingray, Dasyatis chrysonota (Smith, 1828) (Chondrichthyes: Dasaytidae), off the coast of Israel. Acta Adriatica 45 (1): 107-112.

Harzallah A. 2003. Transports de polluants dans la lagune de Bizerte simulé par un modèle de circulation de l'eau. Bulletin de l'Institut des Sciences et Technologies de la Mer de Salammbô 30 (numéro special): 121-133.

Iglésias S.P., Sellos D.Y., Nakaya K. 2005. Discovery of a normal hermaphroditic chondrichthyan species: Apristurus longicephalus. Journal of Fish Biology 66 (2): 417-428. DOI: 10.1111/j.0022-1112.2005.00607.x

Irvine S.B., Laurenson L.J.B., Stevens J.D. 2002. Hermaphroditism in the southern lantern shark, Etmopterus granulosus. In: International Congress on the Biology of Fish. 21-26 July 2002. University of British Columbia, Vancouver Canada. http://www-heb.pac.dfompo.gc.ca/congress/2002/DeepSea/Irvine2.pdf

Kabasakal H. 2002. Elasmobranch species of the seas of Turkey. Annales, series Historia Naturalis 12 (1): 15-22.

Louiz I., Menif D., Ben Attia M., Ben Hassine O.K. 2007. Incidence des déformations squelettiques chez trois espèces de Gobiidae de la lagune de Bizerte (Tunisie). Cybium 31 (2): 209-216.

McEachran J.D., Capapé C. 1984. Dasyatidae. Pp. 197-201. In: Whitehead P.J.P., Bauchot, M.L., Hureau J.C., Nielsen J., Tortonese. E. (eds), Fishes of the North-western Atlantic and the Mediterranean. Vol. 2. UNESCO, Paris.

Mellinger J. 1989. Reproduction et développement des Chondrichthyens. Océanis 15: 283-303.

Mnasri N., Boumaïza M., Capapé C. 2009. Morpological data, biological observations and occurrence of a rare skate, Leucoraja circularis (Chondrichthyes: Rajidae), off the northern coast of Tunisia (central Mediterranean). PanAmerican Journal of Aquatic Science 4 (1): 70-78.
Mnasri N., El Kamel O., Boumaïza M., Ben Amor M.M., Reynaud C., Capapé C. 2010. Morphological abnormalities in two batoid species (Chondrichthyes) from northern Tunisian waters (central Mediterranean). Annales Series Historia Naturalis 20 (2): 181-190.

Mzoughi N., Hellal F., Dachraoui M., Villeneuve J.-P., Cattini C., de Mora S.J., El Abed A. 2002. Méthodologie de l'extraction des hydrocarbures aromatiques polycycliques. Application à des sédiments de la lagune de Bizerte (Tunisie). Comptes Rendus Géoscience 334 (12): 893-901. DOI: $10.1016 / \mathrm{S} 1631-0713(02) 01827-8$

Nair R.V., Soundararajan R. 1973. On an instance of hermaphroditism in the electric ray Narcine timlei (Bloch and Schneider). Indian Journal of Fisheries 20 (1): 260-264.

Neifar L., Euzet L., Ben Hassine O.K. 2000. New species of the Monocotylidae (Monogenea) from the stingray Dasyatis tortonesei Capapé (Euselachii, Dasyatidae) off the Tunisian coast, with comments on host-specificity and the specific identities of Mediterranean stingrays. Systematic Parasitology 47 (1): 43-50. DOI: $10.1023 / \mathrm{A}: 1006354423136$

Orlov A.M. 2011. Record of a tailless Richardson's ray Bathyraja richardsoni (Garrick, 1961) (Rajiformes: Arhynchobatidae) caught off the Mid-Atlantic ridge. PanAmerican Journal of Aquatic Sciences 6 (3): 232-236.

Quignard J.-P., Capapé C. 1972. Cas d'hermaphrodisme chez Raja miraletus L., 1758. Travaux du Laboratoire de Biologie Halieutique de l'Université de Rennes 6: 133-143.

Quignard J.-P., Negla N. 1971. Anomalies au niveau du système génital chez les sélaciens rajiformes. Travaux du Laboratoire de Biologie Halieutique de l'Université de Rennes 5: 121-124.

Ribeiro-Prado C.C., Oddone M.C., Ferreira de Amorim A., Capapé C. 2009. An abnormal hermaphrodite pelagic stingray Pteroplatytrygon violacea (Dasyatidae) captured off the southern coast of Brazil. Cahiers de Biologie Marine 50 (1): 91-96.

Saad A., Séret B., Ali M. 2005. Liste commentée des Chondrichthyens de Syrie. Rapport de la Commission internationale pour l'Exploration scientifique de la Mer Méditerranée 37: 430.

Scenna L.B., Díaz De Astarloa J.M., Cousseau M.B. 2007. Abnormal hermaphroditism in the multipsine skate Bathyraja multispinis (Chondrichthyes, Rajidae). Journal of Fish Biology 71 (4): 1232-1237. DOI: $10.1111 / \mathrm{j} .1095-8649.2007 .01586 . \mathrm{x}$

Séret B., McEachran J.D. 1986. Catalogue critique des types de poissons du Muséum national d'Histoire naturelle (suite). Poissons Batoïdes (Chondrichthyes, Elasmobranchii, Batoidea). Bulletin du Muséum national d'Histoire naturelle de Paris, 4ème série, 8, section A, 4, supplément: 3-50.

Sfakianakis D.G., Koumoundouros G., Divanach P., Kentouri M. 2004. Osteological development of the vertebral column and of the fins in Pagellus erythrinus (L. 1758). Temperature effects on the development plasticity and morpho-anatomical abnormalities. Aquaculture 232 (1-4): 407-424. DOI: $10.1016 /$ j.aquaculture.2003.08.014 
Sloof W. 1982. Skeletal anomalies in fish from polluted surface waters. Aquatic Toxicology 2 (3): 157-173.

DOI: 10.1016/0166-445X(82)90013-3

Yano K. 1995. Reproductive biology of the black dogfish, Centroscyllium fabricii, collected from waters off western Greenland. Journal of the Marine Biological Association of the United Kingdom, 75 (2): 285-310.

DOI: $10.1017 /$ S002531540001818X
Yano K., Tanaka S. 1989. Hermaphroditism in the lantern shark Etmopterus unicolor (Squalidae, Chondrichthyes). Japanese Journal of Ichthyology 36 (3): 338-345.

DOI: $10.1007 / \mathrm{BF} 02905618$

Received: 30 March 2012

Accepted: 22 May 2012

Published electronically: 30 June 2012 